\title{
Sentenza 238/2014: EU Law and EU Values
}

\author{
Bernardo Giorgio Mattarella
}

\begin{abstract}
The relationship between Judgment 238/2014 of the Italian Constitutional Court and EU law is, at first glance, apparently weak, as the subject matter of the former is not governed by the latter, nor there have been any judgments from EU courts regarding the case. However, if one considers the origin and purpose of the EU itself and the state of relations between Italy and Germany, one cannot help but examine the case from a European law perspective. Judgment 238/2014 is relevant to European law in several ways, all of which concern not only military cooperation in the EU but also the protection of human rights, the risk of forum shopping and, above all, how reliable member states are in their mutual relations. European law in turn is relevant to the present case not so much because it offers solutions but because it shows a method for settling clashes between legal systems and illustrates its inherent difficulties. Sentenza 238/2014 is an unpersuasive judgment and can be criticized from different angles: the legal one (international and constitutional law), the factual reconstruction and the judgment's likely effects. There are, however, two possibilities of resolving the situation that Sentenza has produced: firstly the legal one, which involves the use of all possible tools to limit its effects; and secondly the diplomatic one, which implies further negotiations. European law does not provide a ground for a preference between these two options, but it suggests that none of these ways is neglected.
\end{abstract}

\section{Introduction}

Neither the protection nor reparations for the victims of Nazi crimes committed during World War II (WWII) are governed by European law, nor are there EU courts' decisions regarding them. Therefore, one could simply give a negative answer to the four key questions raised by the editors: that Judgment 238/2014 does not have legal implications for European military operations, that it is not an

\footnotetext{
B. G. Mattarella ( $\square)$

LUISS Guido Carli University, Department of Law, Rome, Italy

e-mail: bmattarella@luiss.it 
application of a particular national approach to European issues, that there is not a European special way to state immunity, and that European law is of little help in the issues related to this Judgment.

Nevertheless, it would be a mistake to believe that European law is irrelevant to Judgment 238/2014, and vice versa. Indeed, some background facts need to be taken into consideration: the European integration process started after WWII precisely to ensure peace in Europe by creating ties, not only economic in nature, between European countries. More than 70 years after the end of the war and 60 years after the foundation of the European Communities, we are still discussing reparations for war crimes. Is this a failure for the EU?

Maybe not. The fact that such issues are peacefully negotiated between governments, with legal proceedings before courts and with friendly discussions among scholars, seems to me a success. One reason for optimism is that what has been said so far shows the high standard of human rights protection in the EU. Italian courts, in the cases that we are discussing, have broadly, though possibly improperly, applied the principles of human rights protection that are part of the common legal heritage of all EU member states. Judgment 238/2014 undoubtedly demonstrates that there is a problem between two founding member states of the Union. This is certainly a cause for concern, which should not, however, overshadow the otherwise excellent relations between Germany and Italy. It is in this context that we can reflect both on the implications of Sentenza for EU law and on the indications that EU law can provide for the issues that we are discussing.

\section{Implications for EU Law}

As for the implications of Judgment 238/2014 for EU law, it can easily be affirmed that there is no regional customary policy on state immunity cases in which EU member states are involved. Nor is Sentenza likely to have specific legal implications, for instance concerning European military operations. ${ }^{1}$ There are, however, broader legal implications, both substantive and procedural, that inter alia concern respect for human rights in the EU. On the one hand, the way in which the issue of reparations for war crimes is dealt with in this case could become an important precedent for other violations of human rights, for example concerning immigration and asylum. A violation of human rights, for example, could be found by a national court in the rejection or expulsion of migrants, who could therefore be entitled to compensation. On the other hand, Judgment 238/2014 raises the issue of universal jurisdiction, which could give rise to forms of forum shopping. ${ }^{2}$

\footnotetext{
${ }^{1}$ See also Andreas Zimmermann, chapter 'Would the World Be a Better Place If One Were to Adopt a European Approach to State Immunity?', in this volume.

${ }^{2}$ See also Giovanni Boggero/Karin Oellers-Frahm, chapter 'Between Cynicism and Idealism', in this volume.
} 
In theory, one consequence of this ruling could be the attraction of multiple human rights cases directed towards Italian courts. Such a prospect would be terrible for Italy, whose courts are already heavily engaged in too much litigation. It would be even worse for Europe if a jurisdiction not recognizing state immunity were to be established within its borders, with unforeseeable effects, for example, on the free movement of capital (if the courts of a member state become particularly keen in granting compensation for offenses related to human rights, potential defendants could move their assets out of that state). Nevertheless, these risks should not be overestimated. We must consider the peculiarities of the case, influenced as it is by the special perception in Europe of WWII and Nazi crimes. It is also necessary to take into account the circumstances of this particular case and of this Judgment, which was decided by the Italian Constitutional Court (ItCC) with a difficult and not unanimous deliberation. ${ }^{3}$

The risks, in fact, are not the worst consequence of the Judgment. More worrying is its effect on the predictability of negotiations on this matter and on the reliability of the negotiating parties. In any negotiation there is always the risk that one of the parties plays according to the rules for as long as it finds it convenient. Such an attitude would be particularly harmful for the EU, where the very idea of the unreliability of a founding member state is unacceptable. Even in this respect, however, the risk should not be overestimated. We must consider, once again, the peculiarities of the case. It is necessary to take into account, above all, the experience of more than 60 years of fruitful negotiations and fair implementation of European law. Overall, we should not overrate the implications of Judgment 238/2014 for European law.

\section{The Suggestions Provided by EU Law}

What indications can European law provide for the case at hand? First of all, customary law does not offer clear indications for this case and a legislative solution is at present quite difficult. Hence, there are a few alternatives to further negotiations. Secondly, there is the theme of the dialogue between courts and of the conditional approach; in this respect, European law provides important indications that demonstrate the complexity of the matter.

European law implies a certain degree of mutual trust between national courts and between these national courts and European courts; trust is necessary for the implementation of European law, which requires coordination and responsibility. However, coordination is more difficult to achieve between courts than between governments because courts cannot negotiate and agree on individual cases. Consequently, the possibility that government decisions are ruled out by court decisions is a risk that needs to be eliminated.

\footnotetext{
${ }^{3}$ See Sabino Cassese, chapter 'Recollections of a Judge', in this volume.
} 
Coordination and accountability in the EU are necessary for all actors, including courts, which, in turn, must safeguard the rule of law and protect individual rights without infringements or compromises. Within this framework, we can deal with the 'barking or biting' issue, which is raised by the 'Solange approach', by the counterlimits doctrine, and by the theory of equivalent protection. Barking is useful as long as a court does not need to bite, but is effective only if everyone knows that the court has teeth enough to bite. One bite, from time to time and in exceptional circumstances, can be appropriate and necessary. Of course, an inappropriate bite would be harmful. ${ }^{4}$

\section{Law and Negotiations}

An evaluation of whether Judgment 238/2014 is right or wrong is necessary in order to outline the future path to follow. There are many arguments suggesting that the ItCC's Sentenza is wrong from the point of view of both international law and constitutional law. The Judgment seems to be based on a questionable contrast between the international law principle of immunity and the protection of the rights of the individual granted by national law. It also seems incorrect on the merits because the right to a judge had actually been granted by Germany. ${ }^{5}$ In this respect, though we may have doubts about German legislative and judicial decisions, we must consider Germany's efforts to compensate the victims. We must also acknowledge that the ItCC acted beyond its remit by syndicating those decisions: it did not share the views of German courts and thus stated that there had been no judgments. The ItCC may also have sinned by vanity, searching the 'great judgment', ${ }^{6}$ and may have underestimated or overlooked the effects of its decision, doing little good to constitutional adjudication. $^{7}$

It seems to me, however, that the main task ahead is to identify possible solutions in order to limit the negative effects of Sentenza 238/2014 and to highlight the positive elements of the case. The Judgment must be circumscribed as a unique decision: it is unlikely that a similar judgment will be adopted in the future, but it is equally unlikely a revision of the Constitutional Court's position. We cannot realistically expect an overruling, but we can expect a different decision in the future, when based on different facts. There are two different ways out of the current deadlock: legal and diplomatic.

\footnotetext{
${ }^{4}$ See also Raffaela Kunz, chapter 'Teaching the World Court Makes a Bad Case', in this volume.

${ }^{5}$ For a different perspective, see Valerio Onida, chapter 'Moving beyond Judicial Conflict in the Name of the Pre-Eminence of Fundamental Human Rights', in this volume.

${ }^{6}$ Guido Calabresi, Il mestiere di giudice: Pensieri di un accademico americano (Bologna: Il Mulino 2014).

${ }^{7}$ See Sabino Cassese, chapter 'Recollections of a Judge', in this volume.
} 
The legal route is to wait and use all possible legal means to limit the effects of the Sentenza, counting on non-execution of any further judiciary decisions. It seems to me that exclusively choosing this route would be offensive to the dignity of the victims and also to the dignity of constitutional adjudication: Judgment 238/2014 may be criticized, but it is a judgment of a constitutional court and must be executed.

The diplomatic route involves new negotiations, which could be carried out by exploiting the peculiarities of this case, in which there was a certain lack of negotiation - the International Court of Justice had called for 'further negotiations' and the ItCC complained of their absence. The case poses a relatively small issue in financial terms, which could also be addressed by involving the Italian government: Judgment 238/2014, in fact, is rigid on the side of the victims, not on that of the possible payers, so it should not prevent the Italian government from allocating resources in an effort to resolve the case. ${ }^{8}$ Of course, money is not the most important thing in this case; more important is the recognition due to the victims. However, allocating financial resources could be a form of recognition of their suffering and of their rights.

European law does not provide clear indications for either the legal or the diplomatic route: the EU is a community of law, but it is also a community of values. Both ways are eligible, both can be loyally and legally taken.

\section{Reference}

Calabresi, Guido, Il mestiere di giudice: Pensieri di un accademico americano (Bologna: Il Mulino 2014)

Open Access This chapter is licensed under the terms of the Creative Commons Attribution 4.0 International License (http://creativecommons.org/licenses/by/4.0/), which permits use, sharing, adaptation, distribution and reproduction in any medium or format, as long as you give appropriate credit to the original author(s) and the source, provide a link to the Creative Commons license and indicate if changes were made.

The images or other third party material in this chapter are included in the chapter's Creative Commons license, unless indicated otherwise in a credit line to the material. If material is not included in the chapter's Creative Commons license and your intended use is not permitted by statutory regulation or exceeds the permitted use, you will need to obtain permission directly from the copyright holder.

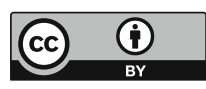

\footnotetext{
${ }^{8}$ See also Francesco Francioni, chapter 'Overcoming the Judicial Conundrum', in this volume.
} 